IFN Working Paper No. 930, 2012

\title{
Cross-Industry Heterogeneity in Export Participation: The Role of Scale Economies in R\&D
}

Shon Ferguson 


\title{
Cross-Industry Heterogeneity in Export Participation: The Role of Scale Economies in $\mathrm{R} \& \mathrm{D}^{*}$
}

\author{
Shon M. Ferguson ${ }^{\dagger}$ \\ Research Institute of Industrial Economics (IFN)
}

September 2012

\begin{abstract}
This paper shows that the R\&D intensity of an industry plays an important role in determining international trade patterns via its effect on scale economies. I first develop a model of trade with heterogeneous firms where firms compete with each other by spending on fixed product development costs such as R\&D. The model predicts that a larger share of firms are exporters in industries where $\mathrm{R} \& \mathrm{D}$ is a large component of total costs. The model also predicts that R\&Dintense industries are less sensitive to trade costs. I find empirical support for these predictions using firm-level data for Swedish manufacturing industries. The results also highlight the importance of controlling for firm size when measuring the firm extensive margin of exports.
\end{abstract}

JEL Classification Codes: F12, L11, O30.

Keywords: International Trade, Trade Costs, Endogenous Sunk Costs.

*I thank Rikard Forslid, Anders Åkerman and the seminar participants at Stockholm University and the 2012 EEA congress for their useful comments and suggestions. Financial support from the Marianne and Marcus Wallenberg Foundation is gratefully acknowledged.

${ }^{\dagger}$ shon.ferguson@ifn.se 


\section{Introduction}

How do exports by firms and industries respond to changes in trade costs? It is now well-established that firms' exporting activities vary considerably even within narrowly defined industries and that export status is correlated with firms' productivity and size. There remains, however, much cross-industry heterogeneity in intra-industry trade patterns that is not fully explained by firm-level variables. While many studies point to demand-side factors such as taste or home bias in determining the extent of intra-industry trade, technological considersations are seldom explored.

In this paper, I argue that the extent of scale economies in a sector plays an imporant role in determining the export orientation of firms in an industry. Manufacturing industries that spend more on fixed production are characterized by having larger firms. Firms in these types of industries also have stronger incentives to export abroad in order to recoup their large fixed cost outlays. Since scale economies drive intra-industry trade in the first place, it is reasonable to expect that differences in the importance of scale economies across industries will have important implications for the pattern of trade.

This work also is motivated by several recent firm-level empirical studies showing a link between exporting and technology investment decisions, such as Lileeva and Trefler (2010), Teshima (2010) and Bustos (2011). ${ }^{1}$ Whereas the "technology upgrading" literature focuses on the response of technology to trade liberalization, I focus on the reverse mechanism, however, namely how the extent of firm-level scale economies drive trade patterns. The feedback effect between technology investments and the decision to export was first explored in the Taiwanese electronics firms by Aw, Roberts, and Winston (2007) and Aw, Roberts, and Xu (2008) using a structural econometric approach. In contrast to these single-industry studies, I develop a framework to analyse cross-industry differences in export patterns across industries that differ in R\&D intensity.

I develop a theoretical model of cross-industry heterogeneity in scale economies based on Melitz (2003). In particular, I assume that firms' spending on product devel-

\footnotetext{
${ }^{1}$ The theoretical model in this paper is also related a recent literature of theoretical models that explore the consequences of trade-induced upgrading. Bas (2008), Antoniades (2008), Bustos (2011) and Vannoorenberghe (2011) develop models whereby firms are heterogeneous with respect to their productivity and self-select not only into exporting but also into investing in productivity-enhancing technology.
} 
opment are embodied in the fixed cost component of firms' increasing-returns-to-scale technology. This assumption is consistent with the fact that firms' spending on these costs often considered as fixed. This paper describes a particular mechanism of nonprice competition in the spirit of Sutton (1991) and Schmalensee (1992) whereby firms compete with each other not only on prices but also on non-price product attributes. Spending on R\&D shifts out the demand for a firm's product. I assume that there are decreasing returns to this $\mathrm{R} \& \mathrm{D}$ spending. These costs represent product development costs, which provide benefits for all markets the firm serves. Firms with higher productivity are willing to spend more on R\&D since their marginal benefit from spending on $\mathrm{R} \& \mathrm{D}$ is greater. Moreover, exporters receive additional revenue in the export market from $R \& D$ spending compared to domestic firms since higher $R \& D$ spending increases foreign demand as well. Non-price competition via R\&D spending is plausible for a variety of industries, especially those where technology investments are associated with fixed costs instead of higher-quality materials. ${ }^{2}$ The theoretical model also matches the evidence that $R \& D$ is highly concentrated among very few firms. Survey data from OECD countries, for example, suggests that most business R\&D is performed by a small number of large firms (OECD 2008)

I test two predictions of the model that are new in the literature. The first new prediction is that $R \& D$-intense industries are more export-oriented, measured as the share of firms that are exporters. The intuition for this result that firms in industries where scale economies are important need to export in order to recoup the fixed costs to develop and produce varieties. The second new prediction is that the export participation of $R \& D$-intense industries is less sensitive to trade costs. The intuition behind the second new prediction is that competition between firms based on $R \& D$ spending makes exporting especially important and hence less sensitive to trade costs.

The hypothesis tests are carried out using firm-level data on the exports of Swedish manufacturing firms. Using data from a small open economy such as Sweden is ideal for this test because the export market will be especially important for sectors with large scale economies. In accordance with the theoretical framework, my dependent variable of interest the share of firms in an industry that are exporters within each industry-destination pair. I interpret this measure of export participation as a scale-

\footnotetext{
${ }^{2}$ This paper thus examines a different set of circumstances than the Quality-Melitz literature by Baldwin and Harrigan (2011) and others, whereby firms invest in better quality materials in order to increase the price of their product.
} 
adjusted measure of the extensive margin. This departs from previous literature who define the extensive margin simply as the number of firms. The advantage of examining the share of firms that export is that it controls for the effect of firm size on the extensive margin. I show in the analysis that using the number of firms as a measure of the extensive margin leads to an underestimation of the extensive margin for concentrated sectors.

Measuring the importance of fixed costs has been a challenge in the Industrial Organization and International Trade literature. Fixed costs and scale economies are often assumed in models but difficult to quantify, especially for cross-industry comparisons. I measure endogenous fixed costs using R\&D as a share of value-added. R\&D intensity strongly associated with average firm size and captures the essense of many fixed costs of product development. Product development costs are less likely to be country-specific, which reduces the risk that $R \& D$ intensity is proxying for export costs. ${ }^{3}$

My empirical results lend support to the theory that scale economies are an important determinant of the extensive margin. R\&D-intense industries are more exportoriented and the share of exporters in R\&D-intense industries is less sensitive to distance. I also devote a considerable part of the analysis to rule out alternative mechanisms that could explain why firms in R\&D-intensive sectors are less sensitive to distance.

This paper is complementary to a recent literature that examines how the sensitivity of the extensive margin to changes in trade costs depends on industry characteristics. Chaney (2008) showed theoretically that the extensive margin is less sensitive to trade barriers in sectors with a higher elasticity of substitution or a lower degree of heterogeneity in productivity. Chaney's predictions found empirical support in work by Crozet and Koenig (2010). Given this previous work, I control for industries' elasticity of substitution and productivity heterogeneity in the empirical analysis. My results confirm the importance of product differentiation and firm heterogeneity but are robust to controlling for these factors. Chen and Novy (2011) show that cross-industry heterogeniety in technical barriers to trade and product weight explains differences in trade integration across manufacturing industries.

\footnotetext{
${ }^{3}$ Sutton (1991) uses product-level advertising intensity as a proxy for the intensity of competition via fixed costs. In the context of international trade, however, advertising is a cost that must be paid separately in each country that the firm exports, making it a poor proxy for economies of scale in production.
} 
The result that a industry's cost structure may affect its response to trade costs is important for three main reasons. First, it sheds light on the forces that drive the export orientation across sectors. Second, this result may have import implications for how different industries respond to trade liberalization and industrial policy. Third, the results imply that $R \& D$-intensive industries are more vulnerable to trade costs since the pursuit of scale economies compels firms to export even when trade costs are high.

The paper is organized as follows. The theoretical framework is presented in section 2. The data sources and a first look at the data is given in section 3 . The main empirical specification and results follow in section 4 , and conclusions are drawn in section 5 .

\section{Theoretical Framework}

\subsection{Set-up}

There are two industries: a manufacturing industry $M$ characterized by increasing returns to scale and homogeneous goods industry $A$ characterized by constant returns to scale. One unit of labor is required to produce a unit of the homogeneous good. The homogeneous good is chosen as the numeraire, and assuming free movement of labor between sectors sets the wage equal to unity.

Consumers have identical utility functions in both countries, dubbed Home and Foreign. Costless trade in the homogeneous goods industry sets the wage in both countries equal to unity. Variable trade costs are assumed to be of the "iceberg" form, so $\tau>1$ units of a variety must be shipped in order for one unit to arrive in the other country. The probability distribution for marginal costs is the same for both countries. All variables that refer to Foreign market are denoted with an asterisk.

Consumer utility is assumed to be Cobb-Douglas between industries and CES within the manufacturing industry. In the same vein as the earlier work on endogenous fixed costs, starting with Sutton (1991), as well as the more recent quality-Melitz literature, an extra firm-specific demand-shifting parameter enters the utility function for manufactures. The larger is $q_{i}$, the greater is the quantity demanded by consumers. This parameter, $q_{i}$, can be influenced by firms' R\&D spending in a manner that will be described in the next section. Each firm's demand-shifting parameter, $q_{i}$, affects 
consumers symmetrically in all countries. The utility function is specified as:

$$
U=C_{M}^{\mu} C_{A}^{1-\mu}, \quad C_{M}=\left(\int_{i=0}^{N} q_{i}^{\frac{1}{\sigma}} c_{i}^{\frac{\sigma-1}{\sigma}} d i\right)^{\frac{\sigma}{\sigma-1}}
$$

where $\mu \in(0,1), C_{A}$ is the consumption of the homogeneous good, $C_{M}$ is the index of consumption for manufactures, $c_{i}$ is the consumption of manufacturing variety $i$ and $\sigma>1$ is the elasticity of substitution. Utility is thus increasing and concave in both $q_{i}$ and $c_{i}$. Each consumer spends a share $\mu$ on manufactures, and demand for variety $i$ is thus:

$$
x_{i}=\frac{p_{i}^{-\sigma} q_{i}}{P^{1-\sigma}} \mu L
$$

where $p_{i}$ is the price of variety $i, L$ is the number of consumers and $P$ is the price index, which can be expressed as:

$$
P=\left(\int_{i=0}^{N} p_{i}^{1-\sigma} q_{i} d i\right)^{\frac{1}{1-\sigma}}
$$

A larger $q_{i}$ increases the total quantity demanded of variety $i$. Labor is the only input to the production process, and costs are composed of a firm-specific marginal labor cost, $a_{i}$, an endogenous, firm-specific $\mathrm{R} \& \mathrm{D}$ fixed cost, $f_{i}$, and an exogenous beachhead cost, $F_{D}$. The fixed cost of product development, $f_{i}$, is not countryspecific. This contrasts with the fixed beachhead costs, which are country-specific. These assumptions are consistent with fixed costs such as product development that are spent once and then provide benefits in every market that the firm serves. I assume that wages for fixed cost and variable cost labor are equal ${ }^{4}$. Since wages are normalized to unity we can write the post-entry cost function for firm $i$ as:

$$
l_{i}=x_{i} a_{i}+f_{i}+F_{D} .
$$

\footnotetext{
${ }^{4}$ Differentiating between fixed cost and variable cost wages in the model would be important when testing with a trade liberalization episode where factor prices may be affected. However, in this analysis I examine trade patterns using variation in distance to various markets and wages are held constant.
} 
Firms set prices equal to marginal cost multiplied by the CES markup:

$$
p_{i}=\frac{\sigma}{\sigma-1} a_{i}
$$

It is important to note that $q_{i}$ does not affect prices paid but only the quantity sold. This formulation is thus conceptually distinct from the quality upgrading literature by Baldwin and Harrigan (2011) and others where investments in quality affect prices.

\subsection{Cutoff Conditions}

The post-entry profits for a domestic firm and exporter situated in Home are:

$$
\begin{gathered}
\pi=q a^{1-\sigma} B-f-F_{D}, \\
\pi_{X}=q a^{1-\sigma}\left(B+\phi B^{*}\right)-f_{x}-F_{D}-F_{X}
\end{gathered}
$$

where $\phi=\tau^{1-\sigma} \in[0,1]$,

$$
B^{*}=\frac{\left(\frac{\sigma}{\sigma-1}\right)^{1-\sigma}}{\sigma \delta P^{*(1-\sigma)}} \mu L^{*}
$$

and $f_{x}$ is the exporter's R\&D spending and $F_{X}$ is the exogenous fixed beachhead cost to serve the export market. The post-entry profits for domestic firms and exporters situated in Foreign are:

$$
\begin{gathered}
\pi^{*}=q a^{1-\sigma} B^{*}-f^{*}-F_{D}, \\
\pi_{X}^{*}=q a^{1-\sigma}\left(B^{*}+\phi B\right)-f_{x}^{*}-F_{D}-F_{X}
\end{gathered}
$$

where $f_{x}^{*}$ is the exporter's R\&D spending.

Since an exporting firm at Home or Foreign spreads its product development costs, $f$ and $f^{*}$ respectively, over both markets, one cannot express the export cutoff marginal cost as a function of export profits alone. The export cutoff, $a_{X}$ or $a_{X}^{*}$, is defined as the marginal cost of the firm whose net profits from serving both markets equals the net profits from only serving the domestic market. The domestic and export cutoffs for Home and Foreign are:

$$
\begin{gathered}
q\left(a_{D}\right) a_{D}^{1-\sigma} B=f\left(a_{D}\right)+F_{D} \\
{\left[q_{x}\left(a_{X}\right)-q\left(a_{X}\right)\right] a_{X}^{1-\sigma} B+\left[q_{x}\left(a_{X}\right)\right] a_{X}^{1-\sigma} \phi B^{*}=f_{x}\left(a_{X}\right)-f\left(a_{X}\right)+F_{X},}
\end{gathered}
$$




$$
\begin{gathered}
q^{*}\left(a_{D}^{*}\right) a_{D}^{*(1-\sigma)} B^{*}=f^{*}\left(a_{D}^{*}\right)+F_{D}, \\
{\left[q_{x}^{*}\left(a_{X}^{*}\right)-q^{*}\left(a_{X}^{*}\right)\right] a_{X}^{* 1-\sigma} B^{*}+\left[q_{x}^{*}\left(a_{X}^{*}\right)\right] a_{X}^{* 1-\sigma} \phi B=f_{x}^{*}\left(a_{X}^{*}\right)-f\left(a_{X}^{*}\right)+F_{X} .}
\end{gathered}
$$

Firms' trade-off between exporting and remaining as a domestic firm can be seen by comparing (1) and (2) or (3) and (4). On the one hand an exporter gains operating profits from the export market and thus is induced to shift its demand to in proportion to levels $q_{x}$ and $q_{x}^{*}$ instead of $q$ and $q^{*}$. On the other hand, an exporter is induced to spend more on $\mathrm{R} \& \mathrm{D}\left(f_{x}\right.$ and $f_{x}^{*}$ instead of $f$ and $\left.f^{*}\right)$. The domestic and export cutoff conditions for Home are illustrated graphically in figure 1.

A parameter restriction is required to ensure that the marginal cost cutoff for exporting is lower than the domestic firm cutoff, which is given later in the paper. In addition, the case where the firm serves the export market only can be ruled out by parameter restrictions discussed in the appendix. As in Helpman, Melitz, and Yeaple (2004), the free entry condition means that both countries share the same cutoffs $a_{D}=a_{D}^{*}, a_{X}=a_{X}^{*}$ and the same demand levels $B=B^{*}$. This implies that both countries share the same cutoff $\operatorname{R\& D}\left(f\left(a_{D}\right)=f^{*}\left(a_{D}\right), f\left(a_{X}\right)=f^{*}\left(a_{X}\right)\right)$ and demand levels $\left(q\left(a_{D}\right)=q^{*}\left(a_{D}\right), q\left(a_{X}\right)=q^{*}\left(a_{X}\right)\right)$.

\subsection{Endogenous Fixed Costs and the Decision to Export}

This model departs from the standard Melitz (2003) formulation by assuming that firm-specific R\&D spending, $f$, influence the firm-specific demand curve-shifting parameter $q$ in the utility function This assumption closely follows the seminal work of Sutton (1991) on endogenous fixed costs in the Industrial Organization literature. This assumption is consistent with fixed cost spending that enhances the attractiveness of a product to a consumer, such as product design, $\mathrm{R} \& \mathrm{D}$, or advertising expenditures that are not country-specific. This formulation is essentially a heterogeneous-firm version of the Schmalensee (1992) model of endogenous fixed costs.

Firms each choose their demand parameter and its associated R\&D cost to maximize post-entry profits. This decision is made jointly with the decision to export or not. The firm thus compares the profits from exporting or not, given that they choose the optimal amount of product development in either case. The optimal spending on product development will differ between exporters and domestic firms, since exporters receive a demand response from both markets, which gives them a stronger incentive to invest in product development. 
A domestic firm's optimal choice of $q$ is the solution to the following profit maximization problem:

$$
\max _{q} \pi=q a^{1-\sigma} B-f(q)-F_{D}
$$

A domestic firm's optimal product development choice can be characterized by the following first order condition:

$$
\frac{\partial f(q)}{\partial q}=a^{1-\sigma} B
$$

The exporter problem differs from the domestic firm problem because it considers the additional operating profit in the export market when it chooses its optimal product development. An exporter solves the following problem:

$$
\max _{q_{x}}\left[q_{x} a^{1-\sigma} B(1+\phi)-f_{x}\left(q_{x}\right)-F_{D}-F_{X}\right]
$$

An exporting firm's optimal decision is determined by the following first order condition:

$$
\frac{\partial f_{x}\left(q_{x}\right)}{\partial q_{x}}=a^{1-\sigma} B(1+\phi)
$$

I assume that product development costs are increasing and convex in the "demand shifter", $q$ :

$$
\begin{gathered}
f(q)=q^{\frac{1}{\theta}}, \\
f_{x}\left(q_{x}\right)=q_{x}^{\frac{1}{\theta}} .
\end{gathered}
$$

where $\theta$ is a parameter common to all firms that determines the convexity of the cost to increase demand. The larger is $\theta$, the easier it is for firms to affect consumer demand by spending more on R\&D. I henceforth refer to differences in $\theta$ as differences in "R\&D intensity" throughout the rest of the paper. It turns out that $\theta$ equals the equilibrium industry ratio of $R \& D$ spending to output.

\subsection{Equilibrium Product Development Spending}

Each domestic firm's equilibrium R\&D spending and its associated effect on demand are found by combining (1), (5) and (7), which provides the following solutions:

$$
q(a)=\left(\frac{\theta}{1-\theta} F_{D}\right)^{\theta}\left(\frac{a}{a_{D}}\right)^{\frac{\theta}{1-\theta}(1-\sigma)}, \forall a \in\left(0, a_{D}\right]
$$




$$
f(a)=\frac{\theta}{1-\theta} F_{D}\left(\frac{a}{a_{D}}\right)^{\frac{1-\sigma}{1-\theta}}, \forall a \in\left(0, a_{D}\right] .
$$

Inspection of (9) and (10) reveals that R\&D spending and its associated effect on demand via $q$ is increasing in its own productivity, $a^{-1}$, since a firm with higher productivity has a higher marginal revenue from product development. However, they are also decreasing in the productivity of the cutoff firm, $\left(a_{D}\right)^{-1}$, since a tougher cutoff leads to a lower price index, which reduces all firms' marginal revenue from product development. R\&D spending is increasing in $\theta$. Inspection of both (9) and (10) reveals that $\mathrm{R} \& \mathrm{D}$ spending for the cutoff firm $\left(a=a_{D}\right)$ is independent of the marginal cost draw, and only depends on the exogenous beachhead cost, $F_{D}$, and R\&D intensity. Note that the expressions above assume no particular probability distribution for the firms' marginal cost draws.

Each exporter's equilibrium R\&D spending and its associated effect on demand are found by combining (1), (2), (3), (6), (8), (9) and (10):

$$
\begin{gathered}
q_{x}(a)=\left(\frac{\theta}{1-\theta} F_{X} \Phi\right)^{\theta}\left(\frac{a}{a_{X}}\right)^{\frac{\theta}{1-\theta}(1-\sigma)}, \forall a \in\left(0, a_{X}\right] \\
f_{x}(a)=\frac{\theta}{1-\theta} F_{X} \Phi\left(\frac{a}{a_{X}}\right)^{\frac{1-\sigma}{1-\theta}}, \forall a \in\left(0, a_{X}\right]
\end{gathered}
$$

where

$$
\Phi \equiv \frac{(1+\phi)^{\frac{1}{\theta-1}}}{(1+\phi)^{\frac{\theta}{\theta-1}}-1} .
$$

One can see in (11) and (12) that an exporter's equilibrium R\&D spending and its associated effect on demand via $q_{x}$ is increasing in own productivity, $a^{-1}$, since a firm with higher productivity has a higher marginal revenue from product development. However, exporter product development is decreasing in the productivity of the cutoff exporter, $a_{X}^{-1}$.

The distribution of R\&D spending by firms with different marginal costs is illustrated in figure 2. The curved lines represent the pattern of spending in the model described in this paper. The curve for marginal costs between $a_{D}$ and $a_{X}$ corresponds to equation (10), while the curve between $a_{X}$ and $a=0$ corresponds to equation (12). The pattern of R\&D spending predicted by Bustos (2011) is illustrated by the horizontal line, $f_{\text {Bustos }}$. The pattern of R\&D spending predicted by Antoniades (2008) 
is linear in marginal cost and upward sloping, denoted by $f_{\text {Antoniades }}$. The advantage of the model in this paper is that it clearly captures the concentration of $R \& D$ spending in the high-productivity firms while not ruling out small amounts of R\&D spending by other surviving firms. In contrast, only firms with marginal cost lower than $a_{h}<a_{X}$ spend on product development in the models of Antoniades (2008) and Bustos (2011).

\subsection{Free Entry Condition}

Firms must pay a fixed cost $F_{E}$ to enter the market prior to finding out their marginal cost. Firms enter until the expected profits from entry equal zero:

$$
\begin{gathered}
E\left(\pi_{i}-F_{E}\right)=0 \\
\Leftrightarrow F_{E}=\int_{a_{X}}^{a_{D}}\left[q a^{1-\sigma} B-f(a)-F_{D}\right] g(a) d a \\
+\int_{0}^{a_{X}}\left[q_{x} a^{1-\sigma} B(1+\phi)-f_{x}(a)-F_{D}-F_{X}\right] g(a) d a .
\end{gathered}
$$

Substituting (9), (10), (11) and (12) into (13), assuming a Pareto distribution for firm marginal costs and integrating provides analytical solutions for the domestic and export cutoff firm marginal cost:

$$
\begin{aligned}
& a_{D}^{k}=\frac{F_{E}}{F_{D}} \frac{\beta(1-\theta)-1}{1+\Theta}, \\
& a_{X}^{k}=\frac{F_{E}}{F_{X}} \Theta \frac{\beta(1-\theta)-1}{1+\Theta}
\end{aligned}
$$

where

$$
\Theta \equiv\left((1+\phi)^{\frac{1}{1-\theta}}-1\right)^{(1-\theta) \beta}\left(\frac{F_{X}}{F_{D}}\right)^{1-(1-\theta) \beta} \in[0,1] .
$$

The term $\Theta$ is a measure of trade freeness that includes the effect of fixed and variable trade frictions, plus the intensity of $R \& D$ competition. The term $\Theta$ decreases 
with trade costs and increases with the intensity of $\mathrm{R} \& \mathrm{D}$ :

$$
\frac{\partial \Theta}{\partial F_{X}}<0, \frac{\partial \Theta}{\partial \phi}>0, \frac{\partial \Theta}{\partial \theta}>0
$$

Substituting (9), (10), (11) and (12) into (1) and (2) provides the parameter restriction ensuring that exporters have lower marginal costs than domestic firms:

$$
\left(\frac{a_{X}}{a_{D}}\right)^{1-\sigma}=\left(\frac{\frac{F_{X}}{F_{D}}}{(1+\phi)^{\frac{1}{1-\theta}}-1}\right)^{1-\theta}>1
$$

The export and domestic cutoffs respond to lower fixed or variable trade costs in the same way as a standard Melitz model, i.e. $\partial a_{D}^{k} / \partial \phi<0, \partial a_{X}^{k} / \partial \phi>0, \partial a_{D}^{k} / \partial F_{X}>0$ and $\partial a_{X}^{k} / \partial F_{X}<0$. More intense R\&D competition results in tougher marginal cost cutoffs for both domestic survival and exporting:

$$
\frac{\partial a_{D}^{k}}{\partial \theta}<0, \frac{\partial a_{X}^{k}}{\partial \theta}<0
$$

\subsection{Testable Implications}

The model's most interesting testable implications center around the effect of $R \& D$ intensity on industry export participation and the sensitivity of export participation to trade costs. The model captures $R \& D$ intensity of the manufacturing industry as the parameter $\theta$ :

$$
\frac{f(a)}{y(a)}=\frac{f_{x}(a)}{y(a)+y_{x}(a)}=\theta
$$

where $y(a)=q a^{1-\sigma} B$ and $y_{x}(a)=q a^{1-\sigma} \phi B$ are the firm-level revenues from the domestic and export market respectively. Combining (1) and (2) provides an expression for the share of surviving firms that export in general equilibrium:

$$
\frac{a_{X}^{k}}{a_{D}^{k}}=\Theta \frac{F_{D}}{F_{X}} .
$$

In this context it is advantageous to define the firm extensive margin as the share of firms that export instead of the number of firms because it controls for systematic differences in firm size across industries. Using the number of exporters as a measure of the extensive margin would be misleading in this context since industry concen- 
tration is correlated with industry export participcation. The main predictions that will be tested in the paper are summarized in the following proposition:

Proposition 1 i) export participation (the share of firms that export) in an industry increases with its R\&D intensity:

$$
\frac{\partial \ln \left(\frac{a_{X}}{a_{D}}\right)^{k}}{\partial \ln \theta}>0 .
$$

ii) Distance affects export participation less in REDD intense industries:

$$
\frac{\partial^{2} \ln \left(\frac{a_{X}}{a_{D}}\right)^{k}}{\partial \ln \phi \partial \ln \theta}<0 .
$$

Proof. The derivatives can be calculated after taking the log of (17).

The intuition behind Proposition 1 is the following: More intense competition between firms via $R \& D$ spending encourages a greater proportion of firms to export and makes competition tougher for non-exporters. The need to spread the fixed cost of $\mathrm{R} \& \mathrm{D}$ across multiple markets makes exporting more attractive to these firms and makes them less sensitive to distance.

\section{$3 \quad$ Data and Descriptive Statistics}

\subsection{Firm-Level Data}

The data I analyze comes from the Swedish Survey of Manufacturers conducted by Statistics Sweden, the Swedish government's statistical agency. I use data for 2005 on manufacturing firms (3-digit NACE rev.1.1 codes 151-366) with 10 or more employees. The survey contains information on R\&D, output, value-added, employment, capital stocks, investment and input use that allow for the calculation of total factor productivity. I merge this data with customs data on firm-level exports by destination country. I also merge the firm-level data with individual-level data on the workers at each firm in order to calculate a measure of firm-level "design intensity". My measure of design intensity is the proportion of workers that are classified as "Physical, mathematical and engineering science professionals" in the Swedish Standard Classification of Occupations (SSYK). A list of the occupations included in the design 
intensity measure is given in the appendix. I calculate firm-level capital intensity as the ratio of tangible assets to value-added.

I also create a control variable to measure firm-level vertical specialization, using the ratio of imported inputs to value-added. Vertical specialization is an important variable to control for in the regression analysis for two reasons. First, vertical specialization is a reason why high-technology industries export that is independent of the fixed-cost mechanism that i pursue in this paper. Second, vertical specialization is a potential industry-level proxy for the ease of transporting goods. It is intuitive that international vertical specialization of production is most prevalent in industries where it is relatively easy to transport components back and forth between countries. Including vertical specialization may thus help to deal with the concern that R\&D intensity may also proxy for the ease of transportation.

The regression analysis includes data on at most 5434 firms for the year 2005, of which 4068 export to at least one country.

\subsection{Industry- and Country-Level Data}

The regressions are performed at the 3-digit NACE industry-destination level. Many of the industry variables I use in the analysis are created by aggregating the firm-level data to the industry-level. I do this to create industry-level averages for productivity, human capital intensity, physical capital intensity, output, value-added and vertical specialization. In this process I also create a variable for the share of firms that export, which is my dependent variable of interest.

Industry-level descriptive statistics, including correlations of R\&D intensity with other industry characteristics, are given in Table 1. R\&D intensity positive and significantly correlated with design intensity and skill intensity and negatively correlated with capital intensity. The very high correlation between R\&D intensity, design intensity and skill intensity suggests that problems of colinearity may result if these variables are included in the same regression. R\&D intensity is positively and significantly correlated with average firm output, value-added and employment. This positive relationship between $R \& D$ intensity and average firm size agrees with the predictions of the theoretical model. A list of the five five most and five least R\&D intensitive sectors is provided in the appendix.

I obtain industry-level estimates of the elasticity of substitution from Chen and 
Novy (2011), who report estimates at the NACE rev.1 level, and convert these to the NACE rev.1.1 level. The degree of heterogeneity in productivity, measured as the slope parameter when approximating the productivity distribution in each industry as Pareto, is derived directly from the Swedish firm-level data. Industry-level substitution elasticity is positively and significantly correlated with R\&D intensity, while the pareto slope parameter and vertical specialization are both negatively correlated with R\&D intensity. Data from at most 53 3-digit NACE rev.1.1 industries enter the analysis.

I use data on distance, population and GDP per capita from CEPII, plus a dummy equal to one if the country is contiguous with Sweden (this includes Finland, Norway and Denmark). Data from at most 181 countries enter the main regression analysis.

\subsection{A First Look at the Data}

I begin by graphically illustrating the connection between industry export participation and various measures that captures the average size of firms in an industry. Figure 3 illustrates that export participation ranges widely for industries with smaller firms on average, whereas export participation is almost always high for industries with larger firms on average. This pattern is similar to the finding by Sutton (1991) in a domestic market context that the "lower bound of concentration" becomes higher as competition via fixed costs becomes more important. While figure 3 is highly suggestive of a relationship between firm size and export participation, it by no means implies that firm size causes export. It may be that firms tend to be large due to success in exporting. Moreover, both average firm size and export participation could be determined by other industry factors.

I continue by examining the pattern of export participation and several primitive industry characteristics that may proxy for the importance of exogenous or endogenous fixed costs. Figure 4 plots industry export participation against the industryaverages of intensity variables: R\&D intensity, design intensity, skill intensity and capital intensity. It turns out that the lower bound of export participation is generally increasing with all of these intensity measures, but the connection is most clear using design intensity and R\&D intensity. Although these graphs do not imply

causality, they do suggest that there is a connection between industries' technological characteristics and their export orientation. 
In an effort to understand the industry-level patterns of export participation, I first run a simple industry-level regression of industry characteristics on the share of exporters, total exports and the number of exporters, in log-log form. Data for 53 3-digit NACE rev.1.1 industries enter the regressions. These results are presented in Table 2. Column (1) of Table 2 present the results of regressing the share of firms that export in each industry on R\&D intensity respectively, as well as a several other industry-level controls. The results in column (1) illustrates that R\&D intensity is significant explanatory factors for the share of firms in an industry that export. The regression results in column (2) reveals that $R \& D$ intensity is also significantly related to variations in total exports across manufacturing industries. This suggests that exports of Swedish R\&D-intense goods may be driven by the forces of comparative advantage, though we are able to rule that out in the main analysis. Finally, the results in column (3) indicates that $\mathrm{R} \& \mathrm{D}$ intensity has a significant relationship with the number of firms that export in each industry. This last result illustrates how important it is to account for firm size differences when measuring the determinants of the extensive margin. If firms are larger in R\&D-intense industries then using numbers of firms as a measure of the extensive margin would bias estimation of the extensive margin.

\section{The Effect of Distance on Export Participation}

\subsection{Empirical Specification}

I now test the hypotheses that export participation in an industry increases with its $\mathrm{R} \& \mathrm{D}$ intensity and the impact of variable trade costs on export participation is dampened by the industry's R\&D intensity. I use variation in distance to export destinations in order to identify how trade costs interact with industry R\&D intensity to affect the share of firms that export. Using distance as a measure of trade costs has two main benefits within this context. First, it is a constant measure over time, which allows me to abstract from dynamic considerations of "export hysteresis" which the theoretical model does not capture. Second, it reduces the potential problem that the demand-shifting parameter $q_{i}$ is capturing an Armington-like preference parameter that is driven by destination-country preferences for Swedish goods.

I employ a simple cross-section OLS regression and report a variety of specifica- 
tions using different types of fixed effects. The empirical specification using R\&D intensity is the following:

$\ln (\text { share })_{i c}=\alpha_{0}+\beta_{1} \ln (R \& D)_{i} \times \ln (\text { dist })_{c}+\beta_{2} \ln (\text { dist })_{c}+\beta_{3} \ln (R \& D)_{i}+\mathbf{X}+\eta+\varepsilon_{c i}$

where $\ln (\text { share })_{i c}$ is the logged share of firms in industry $i$ that export to country $c$, $\ln (R \& D)_{i}$ is the logged R\&D intensity of industry $i, \ln (\text { dist })_{c}$ is logged distance to country $c, \mathbf{X}$ is a vector of countrols, $\eta$ are fixed effects and $\varepsilon_{c i}$ is the error term. The theory predicts that the signs are positive for $\beta_{1}$ and $\beta_{3}$ and negative for $\beta_{2}$. The share of firms that export decreases with distance but increases with an industry's R\&D intensity. The interaction of distance and R\&D intensity is expected to yield a positive coefficient since the importance of scale economies is hypothesized to dampen the negative effect of distance on the extensive margin.

The baseline results for R\&D intensity are presented in Table 3. Beta coefficients and standard errors are reported in order to ease comparison of coefficient magnitudes across different independent variables. The results are robust using a variety of specifications. Column (1) of Table 3 does not use any fixed effects and thus includes a full set of country and industry controls. The main coefficients of interest are $\ln (R \& D)_{i} \times \ln (\text { dist })_{c}$ and $\ln (R \& D)_{i}$ which have the expected positive sign and are both statistically significant at the $1 \%$ level. The country-level controls all have the expected signs and are statistically significant. A higher proportion of firms export to larger and geographically close markets. As the theory suggests, R\&D intensity yields a statistically significant and positive coefficient. A higher proportion of firms thus export in sectors with a high R\&D intensity.

Column (1) of Table 3 also includes control interactions of log distance with the industry control variables. These control interactions help to ensure that it is the interaction of $R \& D$ intensity with distance that is driving our result and not some other industry characteristics. It turns out that the productivity slope-distance interaction is the only control interaction that is significant across all columns of Table 3. Columns (2) and (3) employ industry and country fixed effects respectively. Finally, column (4) employs country and industry fixed effects, leaving only country-industry interactions. Overall, the R\&D intensity-distance coefficient is statistically significant with stable coefficients throughout the specifications. 


\subsection{Robustness}

As a first robustness check I use design intensity as an alternative measure of product development. The design intensity variable has the advantage that it it is based on far more firm-level observations compared to the $\mathrm{R} \& \mathrm{D}$ variable. The results using design intensity as a proxy for fixed costs of product development are presented in Table 4. Again, the design intensity-distance interaction term is statistically significant with the expected sign across all specifications.

The result that $R \& D$-intense industries are less sensitive to trade costs agrees with the theoretical framework where these activities contribute to fixed costs of production. It is important, however, to rule out other potential mechanisms that could explain why firms in skill intensive sectors are less sensitive to distance. I now discuss each of these alternative mechanisms and show that they cannot explain the pattern of export participation that I observe in the data.

One concern is that the results are driven by the fact that Sweden has a relative abundance of human capital, which gives it a comparative advantage in the production of R\&D-intensive goods. The theoretical model of Bernard, Redding, and Schott (2007) shows, however, predicts that comparative advantage industries are more sensitive to changes in trade costs, not less. In their analysis they show that a trade liberalization between two countries leads to a stronger selection effect in each country's comparative advantage industry. The reason is that lower trade costs increase the price of the abundant factor, which toughens competition between firms in the comparative advantage industry. Since this effect works via the factor prices, comparative advantage would not explain sensitivity to differences in distances across destinations. We can thus rule out that comparative advantage is driving the results.

Another concern is that the results are driven by exports of R\&D-intense goods to Asia, which happens to be a long way from Sweden. I adress this concern by running the baseline regression with the full set of country and industry fixed effects and dropping observations for China, Hong Kong, Indonesia, Japan, Malaysia, Singapore, South Korea, Taiwan, Thailand, and the Phillipines. The results of this restricted regression are illustrated in the first column of Table 5. The results on the R\&D intensity-distance interaction term remain significant.

Another concern is that it may be within-industry heterogeneity in R\&D intensity that are driving the results. If only the most R\&D-intense firms sell to distant markets then this would reduce the explanatory power of our industry-level R\&D intensity 
measure. I test for the importance of "destination sorting" by calculating the average R\&D intensity of firms by industry-destination pairs and including this as a control variable. The results of adding these additional industry-destination controls are provided in column (2) of Table 5 . The results suggest that destination sorting is not driving the results. Finally, I run the same regression as the baseline with country and industry fixed effects and include all firms with 5 employees or more. The results are unchanged, as illustrated in column (3) of Table 5.

Overall, the robustness checks suggest that the industry-level R\&D intensity variable captures the extent of scale economies and that the relationship between R\&D intensity, distance and exports cannot be explained by comparative advantage, firm heterogeneity or destination sorting.

\section{Conclusions}

The purpose of this paper was to show that scale economies are an important determinant of the extensive margin of trade. I develop a model of trade with heterogeneous firms that parameterizes an industry's R\&D intensity. The first new prediction is that industries that are more R\&D-intense are more export-oriented. The second new prediction is that industries where $R \& D$ is important respond less elastically to trade liberalization along the extensive margin. I take these predictions to the Swedish firm-level data and find evidence that agrees with the model's predictions.

The result that scale economies significantly affect export patterns may have useful applications for trade policy. In particular, the result that industries with large scale economies are less responsive to trade costs may imply that these same industries are less responsive to changes in tariffs. Another implication is that R\&D-intensive industries are more vulnerable to trade costs since they are forced to pay them in order to reach export markets in pursuit of scale economies. The results suggest that R\&Dintensive industries benefit mainly from trade liberalization through reducing their existing trade costs. Industries that rely less on scale economies, however, benefit from trade liberization mainly though becomming more export-oriented. Testing for cross-industry heterogeneity in responses to trade liberalization would be a logical next step for future research. 


\section{Appendix}

\section{Ruling out the Export-Only Case}

There are three potential cases to rule out. The case first is that the export-only cutoff is the easiest cutoff. The second case is that exporting-only is performed by firms with intermediate marginal cost. The third case is that exporting-only is performed by firms with the lowest marginal cost.

The first case is ruled out by the following parameter assumption:

$$
\left(\frac{a_{X o n l y}}{a_{D}}\right)^{1-\sigma}=\frac{1}{\phi}\left(\frac{F_{X}}{F_{D}}\right)^{1-\theta}>1
$$

where $a_{X o n l y}$ is the marginal cost of the firm exporting only and earning zero profits.

The second case can be ruled out because the profits from serving the domestic market exceed the profits from serving the export market only, for any $a \in\left[a_{X}, a_{D}\right]$. This is intuitive because export profits are always lower than domestic profits, for any given marginal cost level.

The third case can be ruled out because the profits from serving both markets exceed the profits from serving the export market only for any $a \in\left[0, a_{X}\right]$. This is intuitive since any firm that can survive in the export market can make more profits by serving the domestic market as well.

\section{References}

Antoniades, A. (2008). Heterogeneous Firms, Quality, and Trade. unpublished manuscript.

Aw, B. Y., M. J. Roberts, and T. Winston (2007). Export market participation, investments in R\&D and worker training, and the evolution of firm productivity. The World Economy 30(1), 83-104.

Aw, B. Y., M. J. Roberts, and D. Y. Xu (2008). R\&D investments, exporting, and the evolution of firm productivity. American Economic Review 98(2), 451-56.

Baldwin, R. and J. Harrigan (2011). Zeros, quality, and space: Trade theory and trade evidence. American Economic Journal: Microeconomics 3(2), 60-88. 
Bas, M. (2008). Trade, technology adoption and wage inequalities: theory and evidence. PSE Working Papers 2008-06.

Bernard, A. B., S. J. Redding, and P. K. Schott (2007). Comparative advantage and heterogeneous firms. Review of Economic Studies 74(1), 31-66.

Bustos, P. (2011). Trade liberalization, exports, and technology upgrading: Evidence on the impact of mercosur on argentinian firms. American Economic Review 101 (1), 304-40.

Chaney, T. (2008). Distorted gravity: The intensive and extensive margins of international trade. American Economic Review 98(4), 1707-21.

Chen, N. and D. Novy (2011). Gravity, trade integration, and heterogeneity across industries. Journal of International Economics 85(2), 206-221.

Crozet, M. and P. Koenig (2010). Structural gravity equations with intensive and extensive margins. Canadian Journal of Economics 43(1), 41-62.

Helpman, E., M. J. Melitz, and S. R. Yeaple (2004). Export versus fdi with heterogeneous firms. American Economic Review 94(1), 300-316.

Lileeva, A. and D. Trefler (2010). Improved Access to Foreign Markets Raises PlantLevel Productivity... for Some Plants. Quarterly Journal of Economics 125(4).

Melitz, M. J. (2003). The impact of trade on intra-industry reallocations and aggregate industry productivity. Econometrica 71(6), 1695-1725.

OECD (2008). OECD Science, Technology and Industry Outlook 2008. Paris: Organisation for Economic Co-operation and Development.

Schmalensee, R. (1992). Sunk costs and market structure: A review article. Journal of Industrial Economics 40(2), 125-34.

Sutton, J. (1991). Sunk Costs and Market Structure: Price Competition, Advertising, and the Evolution of Concentration. MIT Press, Cambridge, Mass.

Teshima, K. (2010). Import competition and innovation at the plant level: evidence from Mexico. unpublished manuscript.

Vannoorenberghe, G. (2011). Trade between symmetric countries, heterogeneous firms, and the skill premium. Canadian Journal of Economics 44(1), 148-170. 


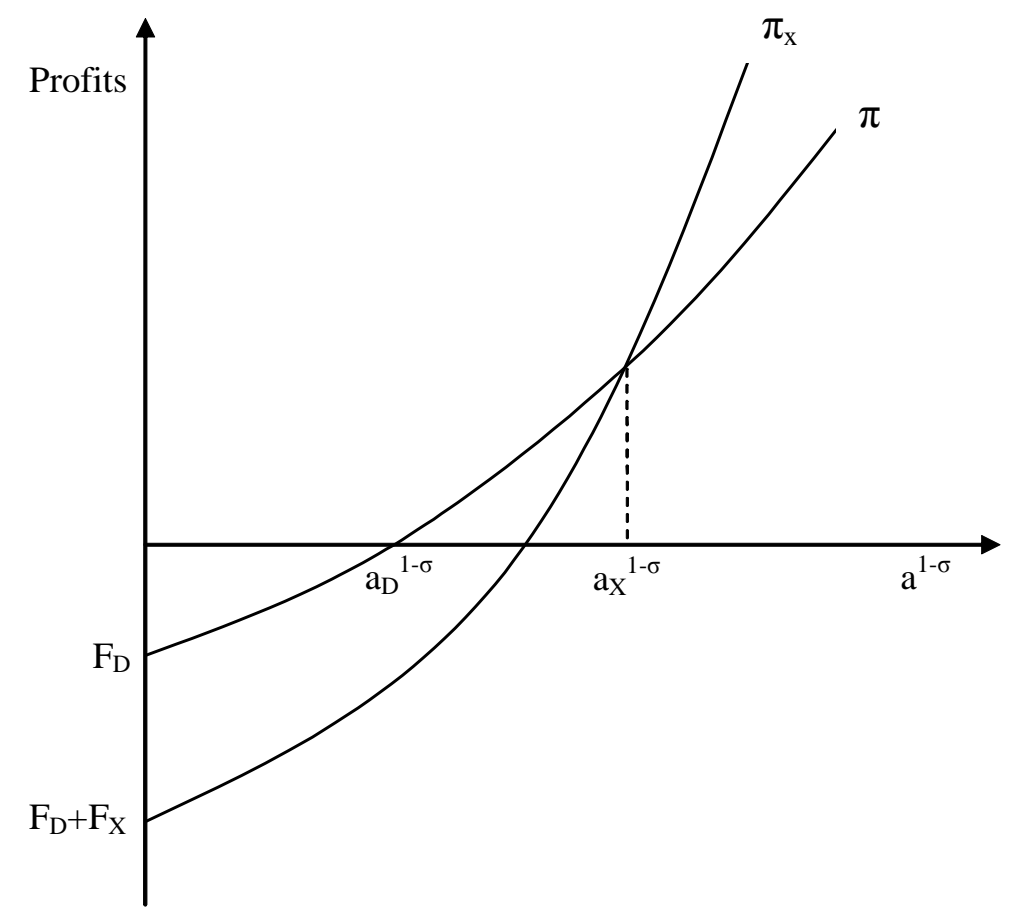

Figure 1: Domestic and Export Cutoff Conditions

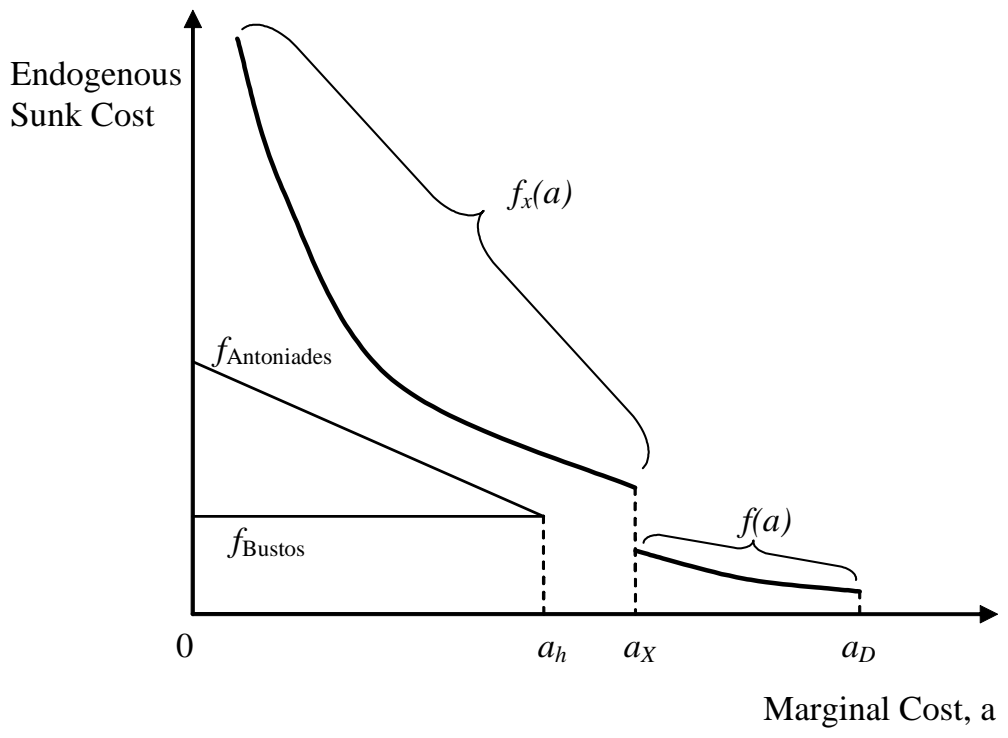

Figure 2: Graphical Representation of Firms' Endogenous Sunk Cost Choice for a Given Marginal Cost 

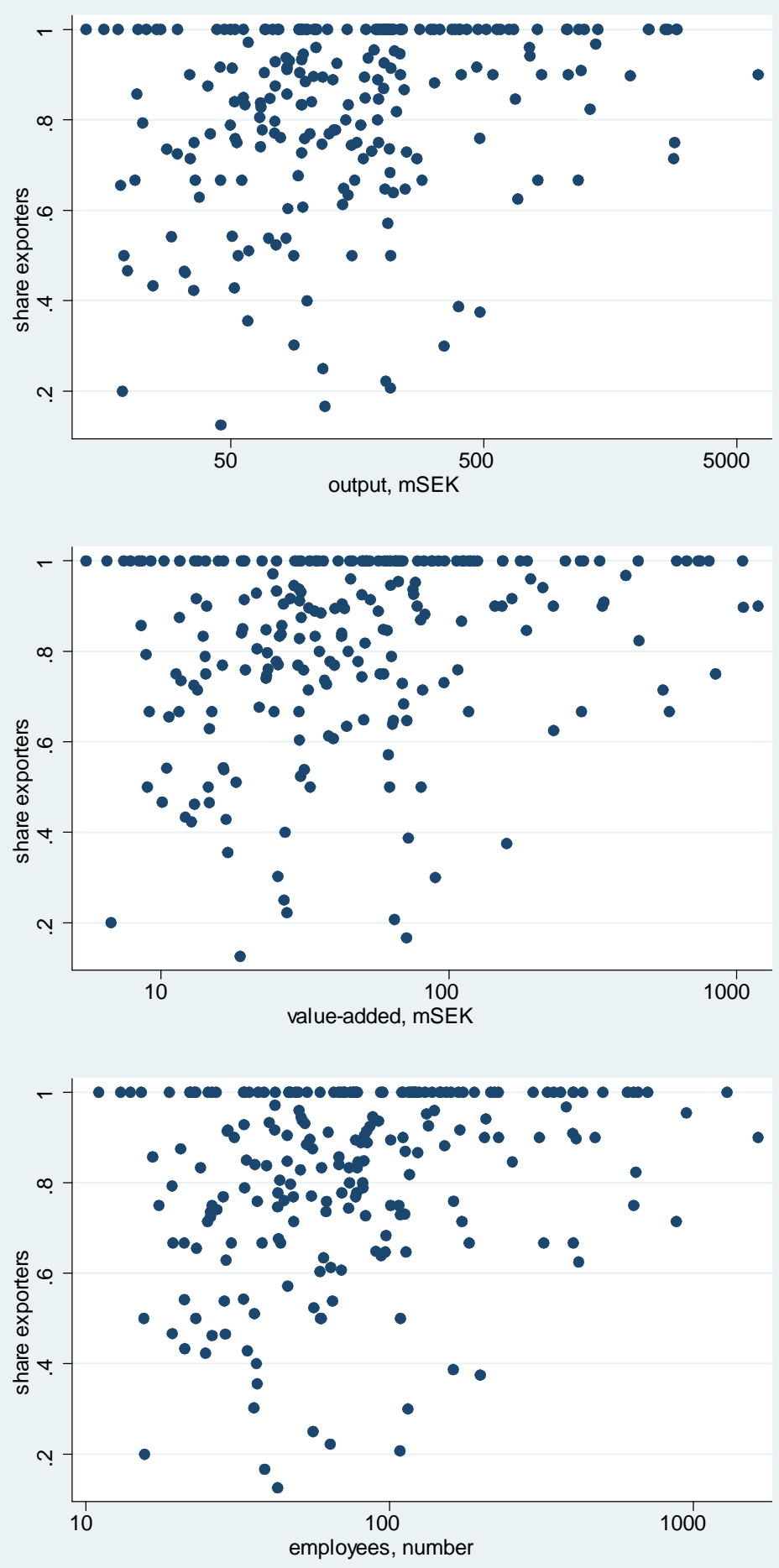

Each dot represents a NACE rev. 3 industry. Source: Statistics Sweden

Figure 1: Industry-level export participation and average firm size 



Each dot represents a NACE rev.3 industry.

Source: Statistics Sweden

Figure 2: Export participation and selected industry characteristics (intensities) 
Table 1: Industry-level descriptive statistics

\begin{tabular}{lcccccc}
\hline Variable & Mean & $\begin{array}{c}\text { Std. } \\
\text { Dev }\end{array}$ & Min & Max & $\begin{array}{c}\text { Corr. coeff } \\
\text { R\&D int. }\end{array}$ & Obs. \\
\hline R\&D intensity & & & & & & \\
design intensity & 0.06 & 0.09 & 0.00 & 0.37 & - & 53 \\
skill intensity & 0.04 & 0.05 & 0.00 & 0.20 & $0.86^{*}$ & 56 \\
capital intensity & 0.22 & 0.11 & 0.07 & 0.55 & $0.72^{*}$ & 56 \\
vertical specialization: inputs/VA & 0.59 & 0.39 & 0.13 & 2.44 & -0.10 & 56 \\
productivity heterogeneity: slope & 1.07 & 0.12 & -0.69 & 0.34 & -0.02 & 56 \\
substitution elasticity & 7.27 & 3.59 & 0.21 & 2.44 & -0.13 & 56 \\
average value-added (mSEK) & 104 & 207 & 9 & 1186 & $0.71^{*}$ & 56 \\
average output (mSEK) & 357 & 853 & 20 & 6066 & $0.63^{*}$ & 56 \\
average employment & 145 & 247 & 20 & 1636 & $0.60^{*}$ & 56 \\
& & & & & & \\
\hline
\end{tabular}

Note: based on observations in Table 2, column (2). * indicates a correlation coefficient significant at 10\% level. Each observation represents a 3-digit NACE rev. 1.1 industry.

Table 2: R\&D intensity and export participation

\begin{tabular}{|c|c|c|c|}
\hline Dependent variable: & $\begin{array}{c}\text { share } \\
\text { export }_{i} \\
(1) \\
\end{array}$ & $\begin{array}{c}\log (\text { total } \\
\left.\text { exports }_{\mathrm{i}}\right) \\
(2) \\
\end{array}$ & $\begin{array}{c}\log (\text { number } \\
\text { exporters } \\
\text { i }) \\
(3)\end{array}$ \\
\hline $\log \left(\mathrm{R} \& \mathrm{D}\right.$ intensity $\left._{\mathrm{i}}\right)$ & $\begin{array}{c}0.0397 * * \\
(0.0196)\end{array}$ & $\begin{array}{c}0.197 * * * \\
(0.0717)\end{array}$ & $\begin{array}{l}-0.0775 \\
(0.0683)\end{array}$ \\
\hline $\log \left(\right.$ cap. intensity $\left.\mathrm{y}_{\mathrm{i}}\right)$ & $\begin{array}{l}0.0972 * \\
(0.0544)\end{array}$ & $\begin{array}{c}0.639 * * * \\
(0.234)\end{array}$ & $\begin{array}{l}-0.150 \\
(0.188)\end{array}$ \\
\hline $\log \left(\right.$ sub elast $\left.t_{i}\right)$ & $\begin{array}{c}0.00892 \\
(0.00871)\end{array}$ & $\begin{array}{c}0.0357 \\
(0.0237)\end{array}$ & $\begin{array}{c}0.0328 \\
(0.0245)\end{array}$ \\
\hline $\log \left(\right.$ slope $\left._{\mathrm{i}}\right)$ & $\begin{array}{l}0.135^{* *} \\
(0.0525)\end{array}$ & $\begin{array}{c}-0.653 * * * \\
(0.221)\end{array}$ & $\begin{array}{c}-0.712 * * * \\
(0.204)\end{array}$ \\
\hline $\log \left(\right.$ vertical $\left._{\mathrm{i}}\right)$ & $\begin{array}{c}-0.444 * * * \\
(0.154)\end{array}$ & $\begin{array}{l}-0.238 \\
(1.365)\end{array}$ & $\begin{array}{c}0.117 \\
(0.913)\end{array}$ \\
\hline $\begin{array}{l}\text { Observations } \\
\text { R-squared }\end{array}$ & $\begin{array}{c}53 \\
0.244\end{array}$ & $\begin{array}{c}53 \\
0.381\end{array}$ & $\begin{array}{c}53 \\
0.231\end{array}$ \\
\hline
\end{tabular}


Table 3: R\&D intensity, export participation and distance

(1)

(2)

(3)

(4)

No fe Industry fe Country fe Both fe

$\log \left(\text { R\&D intensity }_{\mathrm{i}}\right)^{*} \log \left(\right.$ distance $\left._{\mathrm{c}}\right)$

$\begin{array}{llll}0.073 & 0.050 & 0.066 & 0.049\end{array}$

$(0.021)^{* * *}(0.017)^{* * *}(0.020)^{* * *}(0.017)^{* * *}$

$\log \left(\right.$ cap. intensity $\left.\mathrm{y}_{\mathrm{i}}\right) * \log \left(\right.$ distance $\left._{\mathrm{c}}\right)$

0.023

$-0.007$

0.023

$-0.008$

$(0.016)$

$(0.012)$

$(0.015)$

$(0.012)$

$\log \left(\right.$ inputs $\left._{\mathrm{VA}} \mathrm{VA}_{\mathrm{i}}\right) * \log \left(\right.$ distance $\left._{\mathrm{c}}\right)$

$-0.047$

$-0.021$

$-0.045$

$-0.017$

$\log \left(\text { slope }_{\mathrm{i}}\right)^{*} \log \left(\right.$ distance $\left._{\mathrm{c}}\right)$

$(0.019)^{* *}$

$(0.015)$

$(0.018)^{* *}$

$(0.015)$

0.051

0.036

0.050

0.033

$\log \left(\right.$ sub elast $\left._{\mathrm{i}}\right) * \log \left(\right.$ distance $\left._{\mathrm{c}}\right)$

$(0.015)^{* * * *}$

$(0.012)^{* * *}$

$(0.015)^{* * *}$

$(0.012)^{* * * *}$

0.018

0.013

0.019

0.012

$\log \left(\mathrm{R} \& \mathrm{D}\right.$ intensity $\left.\mathrm{j}_{\mathrm{i}}\right)$

(0.015)

(0.012)

(0.015)

(0.012)

0.227

0.249

$\log \left(\right.$ capital intensity $\left._{\mathrm{i}}\right)$

$(0.065)^{* * *}$

$(0.064)^{* * * *}$

0.142

0.144

$(0.077)^{*}$

$(0.082)^{*}$

vertical specialization: $\log \left(\right.$ inputs $\left./ \mathrm{VA}_{\mathrm{i}}\right)$

0.085

0.081

$(0.062)$

(0.063)

Firm heterogeneity: slope ${ }_{\mathrm{i}}$

0.145

0.138

$\log \left(\right.$ substitution elasticity $\left._{\mathrm{i}}\right)$

$$
\begin{aligned}
& (0.045)^{* * * *} \\
& 0.075
\end{aligned}
$$

0.087

(0.050)

$(0.053)$

Contiguous $_{\mathrm{c}}$ 0.086

0.084

$(0.006) * * *(0.006)^{* * *}$

$\log \left(\right.$ distance $\left._{\mathrm{c}}\right)$

$-0.266$

$-0.268$

$\log \left(\right.$ population $\left._{\mathrm{c}}\right)$

$(0.014) * * *(0.013)^{* * *}$

0.447

0.444

$(0.018)^{* * *}(0.018)^{* * *}$

$\log$ (GDPpercapita)

$0.551 \quad 0.548$

$(0.024)^{* * *}(0.021)^{* * *}$

Observations

4465

4465

4540

4540

R-squared

0.603

0.739

0.734

0.868

$* * * \mathrm{p}<0.01, * * \mathrm{p}<0.05,{ }^{*} \mathrm{p}<0.1$. Standard errors in parenthesis, clustered at the 3-digit NACE rev1.1 level. Dependent variable: $\log$ (share of firms that export), by 3-digit NACE rev.1.1 industry - country pair. All regressions include constant term. 
Table 4: Alternative measure: design intensity

\begin{tabular}{|c|c|c|c|c|}
\hline & $\begin{array}{c}(1) \\
\text { No fe } \\
\end{array}$ & $\begin{array}{c}(2) \\
\text { Industry fe } \\
\end{array}$ & $\begin{array}{c}(3) \\
\text { Country fe } \\
\end{array}$ & $\begin{array}{c}(4) \\
\text { Both fe } \\
\end{array}$ \\
\hline $\log \left(\text { design intensity }_{\mathrm{i}}\right)^{*} \log \left(\right.$ distance $\left._{\mathrm{c}}\right)$ & $\begin{array}{c}0.057 \\
(0.017)^{* * *}\end{array}$ & $\begin{array}{c}0.057 \\
(0.020)^{* * *}\end{array}$ & $\begin{array}{c}0.060 \\
(0.015)^{* * *}\end{array}$ & $\begin{array}{c}0.054 \\
(0.017)^{* * *}\end{array}$ \\
\hline $\log \left(\right.$ cap. intensity $\left.{ }_{\mathrm{i}}\right) * \log \left(\right.$ distance $\left._{\mathrm{c}}\right)$ & $\begin{array}{c}0.025 \\
(0.016)\end{array}$ & $\begin{array}{l}-0.001 \\
(0.016)\end{array}$ & $\begin{array}{c}0.030 \\
(0.014)^{* *}\end{array}$ & $\begin{array}{c}0.000 \\
(0.015)\end{array}$ \\
\hline $\log \left(\right.$ inputs $\left./ \mathrm{VA}_{\mathrm{i}}\right) * \log \left(\right.$ distance $\left._{\mathrm{c}}\right)$ & $\begin{array}{c}-0.045 \\
(0.018)^{* *}\end{array}$ & $\begin{array}{l}-0.025 \\
(0.016)\end{array}$ & $\begin{array}{c}-0.042 \\
(0.017)^{* *}\end{array}$ & $\begin{array}{l}-0.019 \\
(0.014)\end{array}$ \\
\hline $\log \left(\right.$ slope $\left._{\mathrm{i}}\right) * \log \left(\right.$ distance $\left._{\mathrm{c}}\right)$ & $\begin{array}{c}0.026 \\
(0.014)^{*}\end{array}$ & $\begin{array}{c}0.021 \\
(0.012)^{*}\end{array}$ & $\begin{array}{c}0.027 \\
(0.014)^{*}\end{array}$ & $\begin{array}{c}0.021 \\
(0.012)^{*}\end{array}$ \\
\hline $\log \left(\right.$ sub elast $\left._{\mathrm{i}}\right) * \log \left(\right.$ distance $\left._{\mathrm{c}}\right)$ & $\begin{array}{c}0.036 \\
(0.017)^{* * *}\end{array}$ & $\begin{array}{c}0.032 \\
(0.014)^{* *}\end{array}$ & $\begin{array}{c}0.033 \\
(0.015)^{* *}\end{array}$ & $\begin{array}{c}0.029 \\
(0.013)^{* *}\end{array}$ \\
\hline $\log \left(\right.$ design intensity $\left._{\mathrm{i}}\right)$ & $\begin{array}{c}0.183 \\
(0.070)^{* *}\end{array}$ & & $\begin{array}{c}0.188 \\
(0.064)^{* * *}\end{array}$ & \\
\hline $\log \left(\right.$ capital intensity $\left._{\mathrm{i}}\right)$ & $\begin{array}{c}0.163 \\
(0.075)^{* *}\end{array}$ & & $\begin{array}{c}0.166 \\
(0.081)^{* *}\end{array}$ & \\
\hline vertical specialization: $\log \left(\right.$ inputs/VA $\left.\mathrm{A}_{\mathrm{i}}\right)$ & $\begin{array}{c}0.065 \\
(0.056)\end{array}$ & & $\begin{array}{c}0.070 \\
(0.060)\end{array}$ & \\
\hline Firm heterogeneity: slope $_{i}$ & $\begin{array}{c}0.091 \\
(0.043)^{* *}\end{array}$ & & $\begin{array}{c}0.076 \\
(0.046)\end{array}$ & \\
\hline $\log \left(\right.$ substitution elasticity $\left._{\mathrm{i}}\right)$ & $\begin{array}{c}0.139 \\
(0.050)^{* * *}\end{array}$ & & $\begin{array}{c}0.166 \\
(0.052)^{* * *}\end{array}$ & \\
\hline Contiguous $_{\mathrm{c}}$ & $\begin{array}{c}0.088 \\
(0.006)^{* * *}\end{array}$ & $\begin{array}{c}0.086 \\
(0.005)^{* * *}\end{array}$ & & \\
\hline $\log \left(\right.$ distance $\left._{\mathrm{c}}\right)$ & $\begin{array}{c}-0.270 \\
(0.014) * * *\end{array}$ & $\begin{array}{c}-0.280 \\
(0.013) * * *\end{array}$ & & \\
\hline $\log \left(\right.$ population $\left._{\mathrm{c}}\right)$ & $\begin{array}{c}0.420 \\
(0.020)^{* * *}\end{array}$ & $\begin{array}{c}0.445 \\
(0.019)^{* * *}\end{array}$ & & \\
\hline $\log$ (GDPpercapita) & $\begin{array}{c}0.523 \\
(0.023)^{* * *}\end{array}$ & $\begin{array}{c}0.548 \\
(0.022)^{* * *}\end{array}$ & & \\
\hline Observations & 4227 & 4227 & 4297 & 4297 \\
\hline R-squared & 0.592 & 0.738 & 0.722 & 0.870 \\
\hline
\end{tabular}

*** $\mathrm{p}<0.01, * * \mathrm{p}<0.05, * \mathrm{p}<0.1$. Standard errors in parenthesis, clustered at the 3-digit NACE rev1.1 level. Dependent variable: $\log$ (share of firms that export), by 3-digit NACE rev.1.1 industry - country pair. All regressions include constant term. 
Table 5: Robustness, R\&D intensity

\begin{tabular}{|c|c|c|c|}
\hline & $\begin{array}{c}(1) \\
\text { Remove } \\
\text { East Asia } \\
\text { countries } \\
\end{array}$ & $\begin{array}{c}(2) \\
\text { industry- } \\
\text { country } \\
\text { controls } \\
\end{array}$ & $\begin{array}{c}\text { (3) } \\
\begin{array}{c}5 \text { employee } \\
\text { cutoff }\end{array} \\
\end{array}$ \\
\hline $\log \left(\mathrm{R} \& \mathrm{D} \text { intensity } \mathrm{y}_{\mathrm{i}}\right)^{*} \log \left(\right.$ distance $\left._{\mathrm{c}}\right)$ & $\begin{array}{c}0.054 \\
(0.019)^{* * * *}\end{array}$ & $\begin{array}{c}0.092 \\
(0.023)^{* * *}\end{array}$ & $\begin{array}{c}0.038 \\
(0.016)^{* *}\end{array}$ \\
\hline $\log \left(\right.$ cap. intensity $\left.\mathrm{j}_{\mathrm{i}}\right) * \log \left(\right.$ distance $\left._{\mathrm{c}}\right)$ & $\begin{array}{c}0.001 \\
(0.012)\end{array}$ & $\begin{array}{c}-0.054 \\
(0.023)^{* *}\end{array}$ & $\begin{array}{l}-0.004 \\
(0.012)\end{array}$ \\
\hline $\log \left(\right.$ vertical $\left._{\mathrm{i}}\right) * \log \left(\right.$ distance $\left._{\mathrm{c}}\right)$ & $\begin{array}{l}-0.021 \\
(0.015)\end{array}$ & $\begin{array}{l}-0.011 \\
(0.019)\end{array}$ & $\begin{array}{l}-0.015 \\
(0.014)\end{array}$ \\
\hline $\log \left(\right.$ slope $\left._{\mathrm{i}}\right) * \log \left(\right.$ distance $\left._{\mathrm{c}}\right)$ & $\begin{array}{c}0.050 \\
(0.012)^{* * *}\end{array}$ & $\begin{array}{l}0.010 \\
(0.019)\end{array}$ & $\begin{array}{c}0.033 \\
(0.014)^{* *}\end{array}$ \\
\hline $\begin{array}{l}\log \left(\text { sub elast }_{\mathrm{i}}\right) * \log \left(\text { distance }_{\mathrm{c}}\right) \\
\log (\text { R\&D intensity } \\
\left.\mathrm{c}_{\mathrm{c}}\right) * \log \left(\text { distance }_{c}\right)\end{array}$ & $\begin{array}{c}0.013 \\
(0.013)\end{array}$ & $\begin{array}{c}0.017 \\
(0.016) \\
-0.043\end{array}$ & $\begin{array}{c}0.020 \\
(0.015)\end{array}$ \\
\hline $\log \left(\right.$ cap. intensity $\left.y_{\mathrm{c}}\right) * \log \left(\right.$ distance $\left._{\mathrm{c}}\right)$ & & $\begin{array}{c}(0.031) \\
0.087 \\
(0.033)^{* *}\end{array}$ & \\
\hline $\log \left(\right.$ vertical $\left._{\mathrm{ci}}\right) * \log \left(\right.$ distance $\left._{\mathrm{c}}\right)$ & & $\begin{array}{l}-0.011 \\
(0.014)\end{array}$ & \\
\hline Observations & 4078 & 2307 & 4592 \\
\hline R-squared & 0.873 & 0.892 & 0.853 \\
\hline
\end{tabular}


Table A1: Swedish Standard Classification of Occupations (SSYK) Codes

Code Description

$21 \quad$ Physical, mathematical and engineering science professionals

2111 Physicists and astronomers

2112 Meteorologists

2113 Chemists

2114 Geologists, geophysicists and related professionals

$2121 \quad$ Mathematicians

$2122 \quad$ Statisticians

2131 Computer systems designers, analysts and programmers

2139 Computing professionals not elsewhere classified

2141 Architects, town and traffic planners

2142 Civil engineers

2143 Electrical engineers

2144 Electronics and telecommunications engineers

2145 Mechanical engineers

2146 Chemical engineers

2147 Mining engineers, metallurgists and related professionals

2148 Cartographers and surveyors

2149 Engineers not elsewhere classified

Source: Statistics Sweden 
Table A2. The five most and five least $R \& D$ intense industries

R\&D intensity Industry description (3-digit NACE rev. 1.1)

Five most R\&D intensive industries:

0.37 Manufacture of motor vehicles

0.36 Manufacture of aircraft and spacecraft

Manufacture of pharmaceuticals, medicinal chemicals and

0.30 botanical products

Manufacture of optical instruments and photographic

0.24 equipment

0.17 Manufacture of office machinery and computers

Five least $R \& D$ intensive industries:

$0.00 \quad$ Manufacture of made-up textile articles, except apparel Manufacture of other products of wood; manufacture of

0.00 articles of cork, straw and plaiting materials

$0.00 \quad$ Printing and service activities related to printing Cutting, shaping and finishing of ornamental and building

0.00 stone

$0.00 \quad$ Miscellaneous manufacturing n.e.c.

Source: SCB, author's calculations 